\title{
Tales from the Irish diaspora during COVID-19: Prompting a future research agenda for global mobility
}

Research Article

Marian Crowley-Henry*, Kim Margaret Coogan, Cora Redmond and Niall Sheil

Maynooth University School of Business, Maynooth University, Co, Kildare, Ireland

\begin{abstract}
The COVID-19 global pandemic raises fundamental questions about the future of global mobility. This paper considers publicly posted blog posts from members of the Irish diaspora during the early months of the global pandemic in 2020. Using real-time self-reporting blogs permitted an unobtrusive snapshot into the living experiences of members of the Irish diaspora during this time. Content analysis was undertaken on a total of fifty-nine individual blogs, and key themes across the blogs are explored. The primary theme of technology as both enabler and inhibiter is unpacked, in relation to global communication, work-life balance and working from home - anywhere in the world. A research agenda pertaining to the future of global mobility is proposed.
\end{abstract}

Keywords: Blogs; COVID-19; Irish diaspora; global mobility; research agenda; technology

(C) Sciendo

\section{INTRODUCTION}

'In what period have so many men been so totally exposed at so fast a pace to such earthquakes of change?' (Mills, 2000 [1959]: 1).

In 1959, the sociologist C. Wright Mills wrote that meteoric macro-structural societal changes would leave multitudes insecure in their societal roles. Since the first quarter of 2020, the COVID-19 global pandemic (WHO, 2020) has touched every corner of the world, leaving death, grief, unemployment, changing work practices and uncertain futures. This paper is situated within the precarious temporal period of the COVID-19 pandemic. It focuses on the topic of global mobility at the micro/individual unit of an analysis rather than the organisational level of global staffing (cf. Collings, Scullion and Morley, 2007; Collings and Sheeran, 2020). Specifically, it shares the living experiences of members of the Irish diaspora during the early weeks of the international travel restrictions. It highlights the dominant concerns across the sample, before proposing a future research agenda which is broad enough to capture the nuance of individual circumstance (e.g., family status, age, gender, etc.) (Gunasekara, Bertone, Almeida and Crowley-Henry, 2021), paradox (Collings, Nyberg, Wright and McMackin, 2021), and consideration of multi-level contexts (individual, organisational and national) (Crowley-Henry, Benson and Al Ariss, 2019).

With increasing numbers of publications concerning the careers of skilled migrants (Tharenou and Kulik, 2020) and self-initiated expatriates (Brewster, Suutari and Waxin, 2021) since 2000, this paper contributes to this scholarship on internationally mobile individuals by exploring real-time experiences and life adjustments for members of the Irish diaspora after the overnight installation of restrictions on mobility and changes to work practices. After a sustained period where the self-initiated global mobility of individuals had become normalised 
and assumed (O'Connor and Crowley-Henry, 2020), seeping challenges had begun to emerge with increased nationalism evidenced in major economies in recent years (Collings and Sheeran, 2020). However, the greatest challenge to global mobility has arguably been the COVID-19 pandemic, which has restricted international travel considerably and forced individuals to re-evaluate their lives and values. The research question at the core of this paper asks how are globally located individuals managing their work and mobility during COVID-19 and what this could mean for the future of global mobility.

The following section firstly shares recent literature pertaining to global mobility and then in relation to work and employment during COVID-19. Next, we introduce our novel research method and sample. Then, we share the broad themes that we found in our analysis, and we present our findings. Finally, we discuss our findings in relation to our research question, and we propose a future research agenda, drawing on our empirical and literature reviews.

\section{LITERATURE REVIEW}

The 2020 world migration report by the International Organization for Migration (IOM, 2020) estimates that $3.6 \%$ of the global population are international migrants (281 million people). In business, management and organisation studies, academic research on the topic of global mobility has burgeoned, exploring topics such as the changing composition of global staff (Collings and Isichei, 2017; Collings, Scullion and Dowling, 2009), different types of global mobility (Al Ariss and Crowley-Henry, 2013; Andresen, Bergdolt, Margenfeld and Dickmann, 2014; Tharenou, 2015), motivations to embark on international career moves (Cerdin, Diné and Brewster, 2014) and the career experiences of skilled migrants (Al Ariss, Vassilopoulou, Ozbilgin and Game, 2013; O'Connor and Crowley-Henry, 2020). The ubiquitous capability of skilled migrants to move transnationally is accepted (O'Connor and CrowleyHenry, 2020; Tharenou and Kulik, 2020).

However, challenges to global mobility (Collings and Sheeran, 2020) and skilled migrants' socialisation (Tharenou and Kulik, 2020) have also been recently expressed. Increased protectionism measures in some developed economies are restricting migration flows and curtailing the openness of receiving economies towards migrants (Collings and Sheeran, 2020). It could be argued that the future of global mobility is in a state of flux and uncertainty. Calls have been made to scrutinise the career-related experiences of globally mobile populations more closely across different units of analysis (Collings et al., 2021; Crowley-Henry, et al., 2019; Gunasekara, et al., 2021), focusing on contextualised careers research (Mayrhofer, Smale, Briscoe, Dickmann and Parry, 2020), over time and circumstance (Gunz and Mayrhofer, 2018) in order to better understand divergent, convergent and/ or crossvergent career trajectories. Moreover, the topic of global mobility during COVID-19 is ripe for scholarly research and analysis.

The extant literature in business and management studies in relation to COVID-19, work and mobility at the individual employee level is fragmented. Work from home (WFH) practices and the continued viability of the teleworking practice is one theme that stands out and has implications for where one geographically/physically works (Caligiuri, De Cieri, Minbaeva, Verbeke and Zimmermann, 2020; Collings and Sheeran, 2020). The CIPD (2021: 3) notes that 'We are in the midst of a radical transformation of working norms and locations'. The COVID-19 crisis has abruptly and extensively moved work firmly into the virtual space (Beaunoyer, Dupéré and Guitton, 2020), and has reinforced at speed the many tasks and jobs that can be effectively completed remotely, lowering costs, and reducing health risk (Friedman, 2020). As a result, it is likely that more work will be conducted remotely in the future.

Related to WFH practices, the blurring of boundaries between work and home, or work-life balance is also addressed in recent literature. Life pre-pandemic required management of competing work and non-work demands with much research highlighting increasing cases of dual working spouses, burnout, and technology blurring the lines between one's personal life and one's work life. Current pandemic circumstances have amplified these concerns and the urgent need for a balanced work life blend (Allen, Merlo, Lawrence, Slutsky and Gray, 2021). Excessive encroaching of one domain into the other results in conflict and undesirable outcomes (Nohe, Meier, Sonntag and Michel, 2015). However, the pandemic has challenged prevailing boundaries demanding renegotiation as individuals strive to work from home while simultaneously participating in care responsibilities, home-schooling, and sharing 
home and working space with family (Allen et al., 2021). When boundaries and desires do not align, dissatisfaction occurs (Kreiner, 2006). It is within this space of shifting circumstances and the renegotiation of boundaries that many workers find themselves currently due to the pandemic. There is greater potential for increased working time and work intensification (Kelliher and Anderson, 2010; Kelliher, Richardson and Boiarintseva, 2019), in work-life blending.

Literature on boundaries suggests that workers with more family demands will experience a greater blurring of roles. This aligns with recent empirical work revealing gender disparities in both the level of housework demanded from female academics working from home when children are present (Yildirim and Eslen $\square$ Ziya, 2021) and the number of working hours of mothers in the general workforce. Indeed, mothers were found to reduce job-related working hours by $20-50 \%$ or four to five times more than fathers of children (Collins, Landivar, Ruppanner and Scarborough, 2021). Thus, it appears that women and their work are disproportionately affected by the pandemic. How individuals have navigated/navigate their work-life interactions during COVID-19 may vary across different countries as well as varying across genders and family responsibilities. We explore this in our empirical study.

Similarly, the variety of experiences across professions has been considered in the literature. The pandemic has had significant influence on labour market dynamics, unemployment, and particularly those in non-standard employment relationships (Spurk and Straub, 2020). Previous economic downturns have proven to result in pay cuts, extended furloughs, and reductions in scheduled hours for those lucky enough to maintain employment (Frone, 2018). Those in non-standard or flexible working relationships, such as gig, agency, and subcontracted workers, may experience the effects of the pandemic in a more pronounced way. They may be experiencing a strange state of prolonged suspension of work and precarity, as some may not have officially lost their jobs but are not being offered short term work or a renewed contract or possibly just have no customers, for example, Uber drivers (Spurk and Straub, 2020). They also may not be entitled to paid sick leave should they contract the virus. Depending on their country of residence, they may not be entitled to government support leaving them exposed to grave financial concerns. This category of worker in flexible employment situations constitutes $17 \%$ of workers in Europe and $16 \%$ in the U.S., making them an important group to consider (Huws, Spencer, Coates, Sverre Syrdal and Holts, 2019). The country of residence, its labour laws and the social welfare supports provided during COVID-19 may be influential drivers pushing or pulling global mobility post-pandemic.

The aforementioned themes can be drawn together under the meta theme of technology and its central role in pandemic life. Technology has overwhelmingly become foundational and central to daily life and work to overcome phased intensifications of quarantine restrictions (Guitton, 2020) and travel barriers in a globally connected context. Large segments of global society depend exclusively on technology to conduct personal communication, individual work assignments, and virtual collaborative tasks (Caligiuri et al., 2020). Literature on COVID-19 and technology also highlights how the gap in pre-existing digital inequalities has widened, compounding vulnerabilities in health and socio-economic matters. As social restrictions become more drastic, technology takes an unprecedented place as the key, or in some circumstances only, vector to conduct work and social life (Beaunoyer et al., 2020). Lack of access to these technologies now severely hampers the ability to earn money, access healthcare, and communicate with loved ones. Technology, as the common medium and enabler through which to function in many key aspects of both personal and working life, leaves individuals at a loss as to how to separate both domains. The flexibility of platform employment, afforded thanks to real-time technological innovation connecting customers and providers, shines the spotlight on the future of gig work and support for gig workers, many of whom are disproportionately negatively affected due to the pandemic. Technology, therefore, is at the core of work practice changes during COVID-19 and also has implications for the future of global mobility.

Next, we turn our attention to our empirical study, before discussing our findings in light of this literature and proposing where future research on global mobility could be directed.

\section{RESEARCH APPROACH \& METHODS}

The aim of our empirical research was to capture the real-time living experiences of a sample of individuals residing internationally and dealing with work and their global mobility during COVID-19. In this way, the study is 'anchored in the worlds of lived experience' (Denzin, 1997: xv). Our approach of analysing publicly posted blogs from members of the Irish diaspora was unobtrusive (Webb et al., 2000), allowing us to capture snapshots of their lived experience without imposition during the global pandemic. This research project was designed to explore the 
narratives (Clandinin and Connelly, 2000; Connelly and Clandinin, 1990, 2006) and experiences of members of the Irish diaspora during COVID-19. Narrative research, as a qualitative research approach, privileges lived and living experiences (Clandinin and Connelly, 2000; Connelly and Clandinin, 1990, 2006). This paper relies on the short narratives from individual Irish migrants to determine common themes related to work and employment across individuals and host countries during the early months of the COVID-19 pandemic (February - July 2020).

For our empirical study, we chose to analyse the blog texts posted by members of the Irish diaspora on a lifestyle section of a public Internet platform to share their stories of living in another country. These include short snapshots of everyday events, thoughts, and interactions. Between the period of 25 February and 2 July 2020, when COVID-19 was being declared a global pandemic, sixty-three consecutive blogs, from sixty-three different bloggers, were posted on this website. After reading each of these, four blogs were discounted as the content had no relevance to COVID-19 or work or global mobility. The remaining fifty-nine blogs are included in our study. An overview of the blog participants is provided in Table 1.

In Table 1 we include participant information such as gender, age range, host country location and family status, if such was provided by the blogger, which was not always the case. Information regarding each blogger was not standardised across all bloggers, with some of the detail regarding their age gleaned or inferred from the blog if not given in the attribution to the blogger. We share this information to emphasise the diversity of individuals included in this study. We conducted document analysis on these blog texts. As a qualitative piece of research, the blog texts were the source of our document analysis (Bowen, 2009; O'Leary, 2014). We focused on comments specifically related to work and global mobility in order to share the individuals' voices and interpret their concerns on these topics (Bowen, 2009).

The length of the blogs ranged from 150 words to 1800 words. Each blog was coded independently by the first, third and fourth authors. All authors of this paper considered the blogs and themes arising therein, discussing collaboratively the dominant foci within and across these blogs. Inter-coder reliability ensures that the themes focused upon in this paper were themes that each researcher found prevalent in the blogs. After several iterations, comparisons and discussions, codes were grouped under themes, which in turn were collapsed into the dominant themes.

While our method of analysing blogs is novel and enables a 'real-time' interpretation of current lived experiences of the Irish diaspora during COVID-19, it has its limitations. Using blog posts, sampling biases may arise: the blogs posted may not be an accurate representation of the Irish diaspora since they only include those using the internet and willing to share their experience publicly. Using blog postings as documents to analyse renders the analysis strictly based on the text/blog provided; there is no facility to seek clarification or to ask probing questions. However, it has been argued that qualitative online research makes valid contributions to knowledge by generating rich insights (Wilkinson and Thelwall, 2011).

Figure 1 depicts the development of our analysis from second order codes (grouped codes from the first order open coding) to the three main themes.

The next section presents our findings in more detail.

\section{FINDINGS}

In our document analysis, we found three underlying themes and structures which influenced the bloggers' perceptions of work and global mobility during this time (see Figure 1). The three main themes that we identified - global communication, work-life blend, and WFH - are independent and co-and inter-dependent. In particular, we found a lot of overlap between the themes of work-life blend and WFH. All three themes, however, could be interpreted as reliant on and as a result of technology as the platform through which work and communication are facilitated. Technology's role and power in enabling communication and connection to work, education and personal contacts was underscored. Work-life blend is the everyday reality of life for workers globally, pronounced even more so in the COVID-19 era of working from home, home schooling and caring responsibilities. The sub-theme of gender disparity and inequality in balancing work and non-work responsibilities is also evident. We consider each of these in relation to the blog posts, next.

The use of technology to navigate both work and personal lives, while adhering to social distancing measures, was apparent across the blogs. Firstly, as a means of global communication in relation to connectivity to family and 
Table 1: Overview of Blog Sample

\begin{tabular}{|c|c|c|c|c|c|c|}
\hline Blog & Age Range & Gender & $\begin{array}{l}\text { Marital } \\
\text { Status }\end{array}$ & Children & Host Country Location & Occupation \\
\hline 1. & $35-40$ & Female & Unknown & Unknown & Athens, Greece & Lawyer \\
\hline 2. & 30 & Female & Single & No & Sri Lanka & $\begin{array}{l}\text { Miscellaneous jobs in host } \\
\text { countries to fund travel }\end{array}$ \\
\hline 3. & $25-30$ & Female & Single & No & Bordeaux, France & Unknown \\
\hline 4. & 28 & Male & Single & No & Tongxiang, China & Departmental head/teacher \\
\hline 5. & Unknown & Female & Unknown & Unknown & New York, USA & Freelance writer and editor \\
\hline 6. & $25-30$ & Female & Unknown & Unknown & London, UK & Reporter \\
\hline 7. & 26 & Male & $\begin{array}{l}\text { Cohabiting with } \\
\text { partner from host } \\
\text { country }\end{array}$ & 1 & Slovakia & $\begin{array}{l}\text { English teacher and } \\
\text { entertainer }\end{array}$ \\
\hline 8. & $30-35$ & Male & $\begin{array}{l}\text { Cohabiting with } \\
\text { partner from } \\
\text { Ireland }\end{array}$ & Unknown & Toronto, Canada & Mental-health worker \\
\hline 9. & $30-35$ & Male & $\begin{array}{l}\text { Cohabiting with } \\
\text { partner from host } \\
\text { country }\end{array}$ & Unknown & Stockholm. Sweden & Business manager \\
\hline 10 & $28-30$ & Male & Unknown & Unknown & New York, USA & Fitness Trainer \\
\hline 11. & $\begin{array}{l}\text { Unknown } \\
(30-40)\end{array}$ & Female & Married & 3 & Bay of Plenty, New Zealand & Writer \\
\hline 12. & Unknown (30s) & Female & Unknown & Unknown & Vancouver, Canada & Employee at law firm \\
\hline 13. & $45-55$ & Female & Married & 1 & Phoenix, Arizona, USA & Manager in an IT multinational \\
\hline 14. & $45-55$ & Female & Cohabiting & 1 & Mexico & Unknown \\
\hline 15. & 40 's & Female & Married & Unknown & Birmingham, U.K. & University professor \\
\hline 16. & 65 plus & Male & Married & 2 & Sheffield, U.K. & Retired teacher \\
\hline 17. & $27-33$ & Female & Married & Unknown & Singapore & Unknown \\
\hline 18. & 46 & Female & Married & Unknown & New York, USA & Author and teacher \\
\hline 19. & $23-26$ & Female & Single & No & New Zealand & $\begin{array}{l}\text { Tourism/service industry } \\
\text { (Working/Holiday) }\end{array}$ \\
\hline 20. & $25-30$ & Female & Unknown & Unknown & London, UK & Musician/DJ \\
\hline 21. & $30-35$ & Female & Unknown & Unknown & Australia & "promising career" \\
\hline 22. & $60 \mathrm{~s}$ & Male & Married & 3 & Budapest, Hungary & Unknown \\
\hline 23. & $20-23$ & Male & Single & No & Beijing, China & Student \\
\hline 24. & $25-30$ & Female & Unknown & Unknown & Phnom Penh, Cambodia & Aid worker \\
\hline 25. & $50-60$ & Female & Married & Unknown & Melbourne, Australia & Unknown \\
\hline 26. & $40-50$ & Female & Married & 2 & Luxembourg & Financial sector \\
\hline 27. & $30-40$ & Female & Married & Unknown & Cayman Islands & Unknown \\
\hline
\end{tabular}




\begin{tabular}{|c|c|c|c|c|c|c|}
\hline Blog & Age Range & Gender & $\begin{array}{l}\text { Marital } \\
\text { Status }\end{array}$ & Children & Host Country Location & Occupation \\
\hline 28. & $25-30$ & Female & Unknown & Unknown & London & Flight Attendant \\
\hline 29. & $20 \mathrm{~s}$ & Female & Unknown & Unknown & Toronto, Canada & Nurse (career break) \\
\hline 30. & Unknown & Male & Unknown & Unknown & Perth, Australia & Doctor \\
\hline 31 & $30-40$ & Female & Married & Unknown & Perth, Australia & Nurse \\
\hline 32. & $30-40$ & Unknown & Unknown & Unknown & London, UK & Physiotherapist \\
\hline 33. & $50-60$ & Unknown & Unknown & Unknown & Saudi Arabia & Healthcare worker \\
\hline 34. & Unknown & Male & Unknown & Unknown & London, U.K. & Comedian and writer \\
\hline 35. & $25-35$ & Female & Married & 2 & Milan, Italy & Office worker \\
\hline 36. & Unknown & Female & Unknown & Unknown & Calabria, Italy & Unknown \\
\hline 37 & $45-55$ & Female & Married & 2 & Verona, Italy & English language teacher \\
\hline 38. & $50-60$ & Female & Unknown & Yes & Central Italy & English teacher \\
\hline 39. & Unknown & Female & Married & Unknown & Forli, Italy & Teacher/translator \\
\hline 40. & $30-40$ & Female & Unknown & 2 & Siciliy, Italy & Musician and English teacher \\
\hline 41. & $35-45$ & Female & $\begin{array}{l}\text { Cohabiting with } \\
\text { native of host } \\
\text { country }\end{array}$ & 1 & Turin, Italy & Teacher \\
\hline 42. & 40 's & Female & Married & No & Seoul, South Korea & Lecturer in university \\
\hline 43. & 30 's-40's & Female & Unknown & Yes & California, USA & Unknown \\
\hline 44. & Unknown & Male & Unknown & Unknown & Santa Barbara, California, USA & Creative business manager \\
\hline 45. & 73 & Male & Married & Unknown & Seoul, South Korea & Language Teacher/Translator \\
\hline 46. & $25-35 ?$ & Male & Unknown & Unknown & Milan, Italy & Unknown \\
\hline 47. & 40 's & Female & Married & No & Milan, Italy & Lecturer in university \\
\hline 48. & 40 's - 50's & Male & Married & 2 & Lombardy, Italy & Small business owner \\
\hline 49. & $20-30$ & Female & Single & No & Lund, Sweden & Student \\
\hline 50. & 26 & Female & Unknown & Unknown & Sydney, Australia & Unknown \\
\hline 51. & $20-30$ & Male & Unknown & Unknown & Atlanta, Georgia, USA & Unknown \\
\hline 52. & $20-30$ & Male & Single & No & Hong Kong & Unknown \\
\hline 53. & 30 's & Male & Unknown & No & Australia & Vet and Writer \\
\hline 54. & 35 & Male & Unknown & Unknown & London, UK & Play write \\
\hline 55. & $30 \mathrm{~s}$ & Male & Cohabitant & Unknown & Canada & Business Owner \\
\hline 56. & $30-40$ & Female & Married & Yes & Melbourne, Australia & Artist and Writer \\
\hline 57. & 37 & Male & Unknown & Unknown & Rome, Italy & Teacher \\
\hline 58. & $40 \mathrm{~s}$ & Female & Married & No & Italy & Unknown \\
\hline 59. & 30 's & Female & Unknown & No & Perth, Australia & Nurse \\
\hline
\end{tabular}




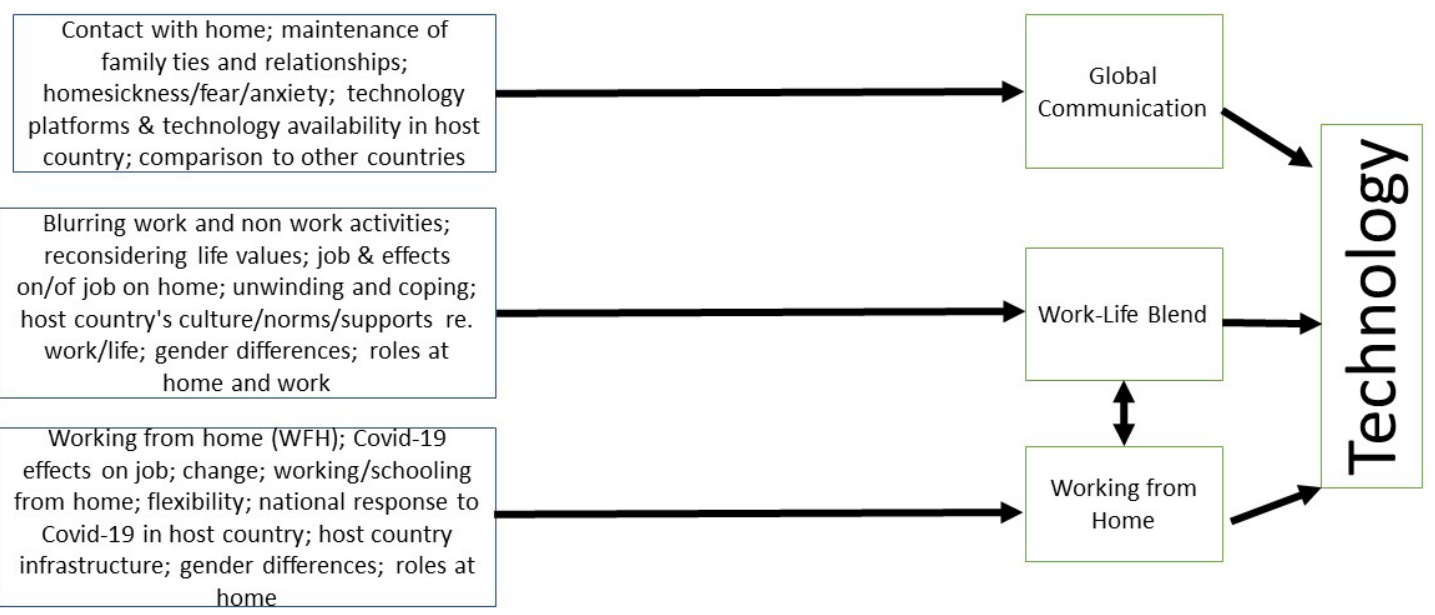

Second order codes from the document analysis of the blogs (where the first order open lists of

Emergent over-arching, meta themes codes were grouped into similar themes)

Figure 1: Moving from First-Order and Second Order Codes to Over-arching Themes

friends internationally, the following text extracts highlight the relevance of being able to stay in regular contact with 'home':

"My parents have discovered FaceTime and we chat a lot more than before the pandemic".

"People back home in Ireland were texting me in different WhatsApp groups".

"We have regular video calls together to keep in touch".

"Zoom quizzes with home every week!".

"Forced time apart from each other physically has also seen many of us communicate across the world more than we ever have virtually".

The physical distance reified through travel restrictions due to COVID-19 was eased through the ability to remain in close contact with loved ones, albeit from a distance. However, the physical distance was a tension among the bloggers, with many expressing the psychological effects of not being able to physically travel and see loved ones in these uncertain times:

"Right now, l'll enjoy my home here: go for walks, meet friends, go to the beach, wait and be patient until I can visit my Ireland home again".

"Mentally, the lockdown has been the hardest for me - not knowing when I can get home to see family and friends safely, is playing on my mind".

Moreover, the country level access to technology varied among the participants, and there was evidence of divergent technological infrastructure across countries, as the following text describes:

"Sadly, [host country]'s quality of internet availability has not quite made it into the 21 st century". 
The divergence between different host countries' level of communication infrastructure could be an impediment to future global mobility to such countries, in particular for individuals that crave reliable communication with loved ones. Where previously the availability of return trips 'home' was possible, COVID-19's travel restrictions has highlighted the importance of alternative means of maintaining contact with loved ones in the home country. How this macro-level influencing factor of telecommunications infrastructure will impact on global mobility and the retention of current global residents remains to be seen.

The second theme (see Figure 1) of work-life blend was clearly evident in the blog texts. The increasing permeability of work and life domains during the COVID-19 era was pronounced, as more and more individuals living at work since their work and homeplace are the same. Given the increase in WFH requirements amidst COVID-19 lockdowns and ongoing restrictions, combined with education from home (during lockdown), and increased caring responsibilities (of children at home and extended family members at a distance), all facilitated through technology, the boundaries between work and non-work have blurred considerably. The following text excerpts share this:

"Online the lines blurred between work and recreation".

"We eat together and watch TV unless I've online meetings I need to log on for. My weekends blur into this".

However, there were variations here depending on the host country. For instance, those based in Scandinavian countries were very positive about the work-life balance culture there. For instance:

"The quality of life is good here ... striking a sustainable work-life balance is encouraged".

"Indeed, working long hours is interpreted as either having too much going on or else being inefficient".

"The country offered a work and life balance that we couldn't achieve in Dublin".

As well as the host country cultural norms concerning work-life balance, the blurring of work and home responsibilities varied depending on the individual's family circumstances, most notably that of child-carers and the requirement to home-school children during the pandemic. The gender imbalance is evident across countries, with more females taking responsibility for childcare and home-schooling, potentially negatively impacting their work and career.

"The novelty of home schooling two children in different school systems, in different languages, while both my husband and I work from home has most definitely worn off".

"Distance learning appears to be working well for some of our friends whose children are older than ours".

"It was hard to work full-time and make sure the schoolwork was covered".

It was notable that issues under the theme of work-life balance/blend were predominantly related to working from home and home schooling, both leading to work intensification and additional stresses. The females in the sample mentioned home schooling and childcare more than the males, suggesting that the responsibilities here, as the literature highlights, fell mainly on their shoulders. Both WFH and home schooling have been facilitated through technology (the overarching theme) and have affected work-life balance to the extent that it is now a blend of work and life (or "living at work" rather than "working from home").

Closely related to the previous theme of work-life overlap, we include the theme of WFH as a separate theme given its prominence as a result of the COVID-19 social distancing restrictions. The texts showed a wide uptake on WFH across the diaspora sample:

"I've been able to continue my work from home since the lockdown".

"I work as a teacher and after a few weeks, I began teaching from home via Zoom".

"My husband and I are lucky; we can work from home". 
Bloggers also appreciated their organisations' support during the pandemic, as the following text excerpts share:

"My employer is actively working to update our sick leave and work-from-home policies to accommodate school closures or self-isolation restrictions that may be ordered in the coming weeks".

"My workplace has invited anybody who can work from home to do so... This is something that has given me some form of relief".

The flexibility offered by appropriate technology was noted, with some bloggers having been able to return to Ireland and work remotely for their host countries.

"My job as X could continue from a laptop, good internet connection and a kitchen table".

The future of global mobility comes under scrutiny when the opportunity to work remotely, from home, anywhere, provided the technological infrastructure is robust, is facilitated. We consider this further in the Discussion section of this paper.

As the literature review shared, we also found evidence of work intensification within the texts. Due to COVID-19 - being tied to one's home and involuntarily working full-time from home - many bloggers expressed the negative impact this has had on their personal time. Work-life blend, where work invades private time, can lead to work intensification:

"I've actually found, like most of the team, that l'm working even longer hours".

"Schools were told not to reopen after the new-year holiday, so I was in emergency online meetings with colleagues as we prepared to shift to online teaching with a weekend's notice".

The paradox of the positive and negative implications of WFH on employees is reflected in the texts.

The overarching theme of technology and its role as an enabler (and inhibiter if poor or non-existent) dominated the texts. Technology has enabled work and communication to continue despite the inability to physically travel and has facilitated ongoing meaning for people in their varied roles as employees/workers, family members and/ or students. While the theme of technology was common across the blog posts, as an enabler of WFH, education and connection to family, the difference in available supports was apparent. Access to technology is varied, and those with less access to technological connectivity seem to be struggling more. The divide between those with adequate access to, the equipment for, organisational support/endorsement for WFH, and the expertise in different technology platforms to support work, education and communication, and those without was observed. The next section discusses these findings further in light of the implications for further research related to global mobility.

\section{DISCUSSION AND FUTURE RESEARCH AGENDA}

The document analysis we undertook for this study exposed the micro-individual experiences and perceptions concerning work and global mobility at the early stages of the global COVID-19 travel restrictions. Technology is the boundary spanning theme in the recent literature and in our document analysis of the blog texts. While technology has been a focal point in debates concerning the future of work from international research agencies, industry, and consultancy reports (for instance, Deloitte Insights, 2020; Eurofound, 2018a, 2018b; Fuller, Wallenstein, Raman and de Chalendar, 2019; Mc Kinsey, 2017; World Bank, 2019), COVID-19 has accelerated the 'changing workplace' (Kowalski and Loretto, 2017: 2233) across the globe. The role of technology is paradoxical as an enabler of global work and communications, while also an inhibiter - depending on the telecommunications infrastructure available for the individual. In this section we discuss the themes from our study further and propose areas for future research in these different areas. 


\section{Global Communications \& Global Mobility}

Both the literature and our empirical findings underline the fundamental role of technology in enabling communication across borders, with implications for global work and communication in the future (Friedman, 2020; Hite and McDonald, 2020). With regard to global mobility and the future of global mobility, it is clear that a reliable and consistent means of communicating internationally is essential. Akkermans, Richardson and Kraimer (2020) conceptualise the pandemic as a career shock (defined as an external event outside of the individual's control). They highlight the importance of actively developing specific career competencies and behavioural and psychological strategies to manage career shocks, including developing/maintaining strong social ties and being communicative. Restubog, Ocampo and Wang (2020) also highlight the importance for individuals to feel in control amidst the chaos of the pandemic. While the blog texts we analysed were written during the first months of the global pandemic, it was already apparent that the host and home countries' respective telecommunication infrastructure was crucial to enabling ongoing communications across the globe despite international travel restrictions. With physical travel curtailed, telecommunication was the sole means of maintaining in touch with loved ones internationally. However, we found that access to technology is not universal. This has resulted in a widening gap between those with and without access to or knowledge of technologies to facilitate work and communication (Caligiuri et al., 2020). The discrepancies across countries support the paradox argument (Collings, et al., 2021), where large gaps and variation exist between countries, and even within countries (e.g., urban versus rural locations). We proffer that given the individual experiences during COVID-19, destinations of choice for self-initiated globally mobile individuals will need to ensure investment in telecommunications infrastructure if they hope to attract international talent. Future multidisciplinary research (e.g., across physical and human geography, migration studies, ICT, economics, and international human resource management (global mobility and international flows of human capital)) could explore the relationship between geographic mobility (Choudhury, 2021) and the host country's telecommunications infrastructure enabling communication with 'home'. Similarly, organisations seeking to attract international talent could highlight the technological advances and advantages they provide. Future inter-disciplinary research (e.g., I.T./Technology/ICT and international human resource management) could investigate the importance of the telecommunications infrastructure across host country destinations of multinational corporations in the attraction and decision-making of international employees to relocate there.

Globalisation had reduced the cost of international travel and shortened the time for internationally located individuals to return to their home countries for weekends or family occasions more frequently than in the past. However, more recent concerns pertaining to increased protectionism (Collings and Sheeran, 2020), safety/terrorism in unstable countries moving across national borders (e.g., 9/11), the environmental impact of air travel over the long-term, and the travel restrictions imposed due to COVID-19, leave the future of global mobility uncertain. While telecommunications facilitated ongoing persistent contact with significant others across countries, it is unclear if the uncertainty caused by COVID-19 and the lengthy travel bans resulting from the pandemic will result in return migration and reduced propensity to engage in global mobility. The taken-for-granted and assumed capacity to relocate internationally, which had become normalised for skilled migrants (Tharenou and Kulik, 2020), is now uncertain. There is a requirement for research in this area to capture the migration patterns internationally over the coming months and years to ascertain the true effects of the pandemic on global mobility. Research tracking individuals' international mobility status and intentions pre-pandemic and post-pandemic would provide crucial insights here into the new, contemporary individual motivations of pursing an international career.

\section{Work from Home (WFH) \& Global Mobility}

Due to the pandemic, widescale WFH practices were introduced reactively to allow organisations to continue to deliver goods and services despite social distancing restrictions and public health requirements. There are several positive outcomes of employees being able to negotiate flexible working patterns at their own discretion, including increased organisational commitment (Kelliher and Anderson, 2010) and job satisfaction (Hill, Miller, Weiner and Colihan, 2006; Hyman and Summers, 2004; Kelliher and Anderson, 2010). However, other studies have shown that employees working consistently remotely may feel isolated which can negatively impact their job satisfaction (Cooper and Kurland, 2002) and mental health (Mann and Holdsworth, 2003). A hybrid approach has been suggested by Bloom (2021) where the organisation sets the days for in-office attendance in order to counteract any disadvantages from working remotely. However, the future of WFH practices remains unclear. 
In relation to global mobility, WFH ability brings the country context of where one is physically located while working into the spotlight. For non-front-end workers, the ability to perform one's work role from anywhere in the world, provided the technological resources are available, raises fundamental questions about the future and necessity of global mobility. There is a need for research on the numbers of internationally employed individuals that live in another country, possibly their home country, while working for an organisation in another jurisdiction. A quantitative study could share the scale of this phenomenon. Exploratory studies could also investigate the country, organisational and individual benefits and concerns of such international work, where one does not actually relocate to another country, or where one chooses where one wants to live which may be a different country to where one works. The remuneration, tax, pension, health insurance and legal implications of this practice require urgent attention. This is an area where international finance and international labour law researchers are required to support research in this area and provide proposals for best practice for supranational unions (such as the European Union), individual nations, organisations, and individuals.

Expertise in international finance and law would be required to ensure that organisations comply with both local host country and international regulations. In a global war for talent, talent gaps could be filled by non-resident employees, and a hybrid model of international remote work and regular host country visits may be accommodated. While multinational organisations may be better equipped to deal with the complexities due to their experience in managing employees in different countries, smaller organisations may struggle with the bureaucracy of international taxation and country-specific labour laws. Moreover, future international work practices, including where one works, would need to be negotiated between organisations and individuals, to ensure both parties are satisfied with the arrangement. Some may be in favour of relocation internationally, while for others it may not be an option due to family circumstances or other personal reasons. There is a need for multi-level research across stakeholders on this topic which could dramatically change the face of global mobility and international work.

Organisations may continue using technology for international meetings post-pandemic, thus decreasing financial costs and strengthening corporate social responsibility by reducing their carbon footprint and contributing to positive climate action decisions. However, it is unlikely that technology will completely substitute international and national business travel. International mobility will persist, we argue, as many employees are in roles which are on the front-line and require direct contact with clients and customers. For these, full time WFH practices may not be possible. Global organisations will still need to access their global marketplaces to exert influence, build relationships, and remain competitive. Future research on global mobility could explore typologies of work where international mobility ranges from essential full-time physical relocation to a host country, to essential regular physical presence, to ad-hoc physical presence, to remote physical presence. Rather than a dichotomy of work being categorised as remote or non-remote work, we argue that a more fluid continuum of physical work presence better reflects the diversity of work types and employer needs.

\section{Work-Life Balance \& Global Mobility}

In our analysis of the blog texts and the literature, we could identify the heterogeneity of individuals' work experiences and perceptions pertaining to global mobility during COVID-19. At the individual level, one's personal characteristics (gender, age, marital status, partner from home or host or other country, family ties in host and home country, family status (with detail pertaining to the caring needs of and responsibilities towards dependent others), non-work support in the host country (childcare providers, spousal support, friend support), etc.) are relevant and influence one's international career decisions. Future research needs to be sophisticated in order to better unpack the nuance of individuals' global mobility decisions given their personal circumstances, as well as their ambitions and opportunities for employment in another country.

This is especially relevant concerning work-life balance concerns and the permeability of work and non-work responsibilities. In the blog posts, it was apparent that mothers blogged more about home-schooling demands, for instance. However, even within the pool of home-schooling bloggers, there were evident differences between those home-schooling young children, where they had to devote time to teaching their children themselves, compared to older children in the household engaging in online education classes and home-schooling themselves. This nuance and attention to intersectional factors in future research on individual global mobility trends is required to better explain global mobility attractors and inhibiters across personal circumstances and over time.

Gender is a fundamental attribute that requires more depth of attention if progress in terms of equality is truly to be made. Organisations should proactively address the gendered concerns related to work-life blend and homework intensification. The endemic blurring of work and home life, which causes work intensification for some and 
flexibility for others, requires honest discussions and diverse voices to ensure a comprehensive, inclusive strategy by organisations and a duty of care toward all employees. COVID-19 has forced individuals to deal with overnight change, to consider their responsibilities at home, at work, and further afield (e.g., family in another geographical area), and to cope with the pressures unique to each individual's specific circumstances. While "we are all in this together" with regard to the global pandemic, each individual has experienced the changes enforced by COVID-19 differently, depending on their unique circumstances. Compassion, empathy, and breadth of understanding are required at the organisational level to support the individual circumstances of employees post COVID-19. Research exposing experiences during the pandemic from different perspectives (genders), through methods such as diary studies, should be conducted and used as data to support organisational change practices to better support female employees. It is crucial that heterogeneous voices are listened to and that wide ranging supports are provided to ensure that polarisation of different segments of the labour market does not occur. More research on females' international careers, particularly mothers, is important for understanding why women may embark on international careers, and how 'stickiness' factors pertaining to motherhood and children's schooling may retain families in host countries or force them to return to their home countries for family support in childcare.

Kelliher and Anderson's (2010) study found that an unanticipated consequence of adopting a flexible working arrangement is increased work intensification. This was also found in a study by Baruch and Nicholson (1997) of teleworkers based at home who worked more hours than they were scheduled since there was no formal separation between work and home time. According to Burchell (2002: 72), work intensification is understood to be 'the effort employees put into their jobs during the time that they are working' and usually has negative health associations. More research is required to fully explore the extent of work intensification during COVID-19 that has been experienced by different employees. Employers and governments have a duty of care to support their employees and citizens over different periods of their lifespan, and data pertaining to which employees suffered more from overwork and burnout during this period would be essential to support policies here. Given the mental health challenges that lockdown has exacerbated with the existential fear of contracting COVID-19, research concerning psychological support across countries would be interesting to analyse and incorporate into reviews and ratings for host country destinations of choice.

Technology enables work but also fuels over-work with the capacity to work nonstop, relentlessly (Kelliher and Anderson, 2010). With work intensification and suggestions of employee burnout post COVID-19, research on organisational supports for employees would highlight the divergence or convergence of employer benefits. More importantly, employee ratings of such benefits across organisations and countries would be key data for organisations to assess whether the benefits they provide are appreciated or valued. Comprehensive research undertakings that coordinate multi-level, multi-stakeholder data collection and analysis for the purpose of real management decision making and implementation is necessary.

The blog texts showed gratitude toward organisations that supported employees' WFH practices during the pandemic, where they had to juggle home and family responsibilities. Future research could explore if such organisational supports will persist post the pandemic. With prophecies of the 'great resignation' (Cook, 2021) post-COVID, where employees will quit their jobs to concentrate on life domains that they value more highly, future research needs to examine organisations' roles in supporting work-life balance, psychological wellbeing, and a sustainable workforce over time and circumstance.

\section{Individual Perspectives \& Global Mobility}

In our analysis, contrary to extant literature on the paradox of worker experiences (Huws, et al., 2019; Spurk and Straub, 2020), we did not find texts relating to precarious work or the differentiation of experiences between individuals in different professions (e.g., in gig work or in secure employment). A limitation of using blog posts as the texts for document analysis is that certain populations are excluded in the analysis simply because they did not post a blog. In addition, our research took place over the first months of the global pandemic, where most organisations and employees were patiently waiting to return to pre-pandemic normality and the economic effects of the pandemic had yet to materialise and become pronounced.

While we relied on the document analysis of single, self-reporting blog post texts, similar data could be collected in a more routine manner, such as by analysing regular tweets from the same individuals, which could capture exact periods and circumstances impacting on individuals' work and careers by tracking changes in tweet content over time. Recent developments in data analytics and machine learning (Guitton, 2020) have the potential to analyse vast amounts of texts across heterogeneous individuals to pinpoint critical junctures ('fateful moments', 
Giddens, 1991) in careers, and to compare experiences across individuals. Using social media to collect data from internationally located individuals around the globe would be an unobtrusive method of collecting real-time data from diverse populations to compare variations depending on country of residence, date of posting, and individual differences. With machine learning and algorithmic calculations, the potential future of granular research on currently hard to find international populations (such as those in precarious work) could dramatically change the field and body of knowledge about individual migrants' and groups of migrants' (diaspora) international mobility and career experiences.

\section{CONCLUSIONS}

COVID-19 has juxtaposed the prior taken-for-granted ease-of-mobility assumptions of internationally mobile individuals with the recent travel restrictions experienced due to the pandemic. This paper considers the future of global mobility and global work. The research question that was explored focused on how globally located individuals were managing their work and mobility during COVID-19 and what this could mean for the future of global mobility. The experiences of internationally located individuals from the Irish diaspora were analysed through document analysis of blog texts. The role of technology as the powerhouse which facilitated global communication and work interactions was underlined. The importance of intersectionality and temporal considerations in future research pertaining to motivations to follow an international career or to remain working internationally has been highlighted, where the heterogeneity of individual characteristics provide nuance and explanatory potential for whom international careers will continue to be attractive. The range of work positions internationally, from secure to gig work, suggests a canvas of potential outcomes for different careers, and it is important to consider this range in future research. Finally, multi-level studies, including multi-stakeholders and multidisciplinary insights are recommended to enable a more comprehensive understanding of the motives for global mobility and how global mobility could be supported across country, organisation, and individual levels in the future.

In conclusion, we call on researchers in the domain of international human resource management and global mobility to direct future research toward ambitiously exploring global mobility at and across different levels (the macro/national context, the organisational support context, and the individual circumstance context) (Crowley-Henry et al., 2019); to investigate the heterogeneity and diversity of facilitating and inhibiting factors across countries, organisations and individuals (Collings et al., 2021); and to include details concerning individual intersectional attributes and characteristics that impact on diverse career and global mobility decision making over time and circumstance (Gunasekara et al., 2021).

Dr. Marian Crowley-Henry is Associate Professor of Human Resource Management and Organisational Behaviour at Maynooth University School of Business, Co. Kildare, Ireland. Her research explores micro-level dynamic perspectives on careers, incorporating minority voices across gender and other intersectionalities.

Kim Margaret Coogan is a PhD candidate in Maynooth University School of Business, Co. Kildare, Ireland. Her research focuses on capital mobilisation and transformation during the transition from student to the formal workplace environment.

Cora Redmond and Niall Sheil were research assistants in the Maynooth University School of Business, Co. Kildare, Ireland, on the Maynooth University Experiential Learning Office's SPUR (Summer Programme for Undergraduate Researchers) over the summer of 2020. 


\section{References}

Akkermans, J., Richardson, J. and Kraimer, M. (2020). The COVID-19 crisis as a career shock: Implications for careers and vocational behaviour. Journal of Vocational Behavior, 119, 1-5. DOI: 10.1016/j.jvb.2020.103434.

Al Ariss, A. and Crowley-Henry, M. (2013). Self-initiated expatriation and migration in the management literature: Present theorizations and future research directions. Career Development International, 18(1): 78-96. DOI: 10.1108/13620431311305962.

Al Ariss, A., Vassilopoulou, J., Ozbilgin, M. F. and Game, A. (2013). Understanding career experiences of skilled minority ethnic workers in France and Germany. The International Journal of Human Resource Management, 24: 1236-1256.

Allen, T. D., Merlo, K., Lawrence, R. C., Slutsky, J. and Gray, C. E. (2021). Boundary management and work-nonwork balance while working from home. Applied Psychology, 70: 1, 60-84.

Andresen, M., Bergdolt, F., Margenfeld, J. and Dickmann, M. (2014). Addressing international mobility confusion - developing definitions and differentiations for self-initiated and assigned expatriates as well as migrants. The International Journal of Human Resource Management, 25: 2295-2318.

Baruch, Y. and Nicholson, N. (1997). Home, sweet work: requirements for effective home-working. Journal of General Management, 23(2), 15-30.

Beaunoyer, E., Dupéré, S. and Guitton, M. J. (2020). COVID-19 and digital inequalities: Reciprocal impacts and mitigation strategies. Computers in Human Behavior, 111, 106424-106424.

Bloom, N. (2021). Don't let employees pick their WFH days'. Harvard Business Review. [online] https:// hbr.org/2021/05/dont-let-employees-pick-theirwfh-days?utm_medium=email (May 25, 2021).

Bowen, G. A. (2009). Document analysis as a qualitative research method. Qualitative Research Journal, 9(2), 27-40. DOI: 10.3316/QRJ0902027.

Brewster, C., Suutari, V. and Waxin, M.-F. (2021). Two decades of research into SIEs and what do we know? A systematic review of the most influential literature and a proposed research agenda. Journal of Global Mobility: The Home of Expatriate Management, [online first], DOI: 10.1108/JGM-052021-0054.

Budhwar, P. and Cumming, D. (2020). New directions in management research and communication:
Lessons from the COVID-19 pandemic. British Journal of Management, 31(3), 441-443.

Burchell, B. (2002). The prevalence and redistribution of job insecurity and work intensification. In B. Burchell, D. Ladipo and F. Wilkinson (Eds.), Job Insecurity and Work Intensification (pp. 61-76). London: Routledge.

Caligiuri, P., De Cieri, H., Minbaeva, D., Verbeke, A. and Zimmermann, A. (2020). International HRM insights for navigating the COVID-19 pandemic: Implications for future research and practice. Journal of International Business Studies, 51(5), 697-713.

Cerdin, J. L., Diné, M. A. and Brewster, C. (2014). Qualified immigrants' success: Exploring the motivation to migrate and to integrate. Journal of International Business Studies, 45(2): 151-168.

Choudhury, P. (2021). Geographic mobility, immobility, and geographic Flexibility - A review and agenda for research on the changing geography of work. Academy of Management Annals, [online first]. DOI: 10.5465/annals.2020.0242.

CIPD (2021). Labour Market Outlook. Views from Employers. Winter 2020-21. CIPD in partnership with Adecco. Available at: https://www.cipd.co.uk/ Images/labour-market-outlook-winter-2020-21. pdf_tcm18-90917.pdf (accessed 25 April 2021).

Clandinin, D. J. and Connelly, M. (2000). Narrative Inquiry: Experience and Story in Qualitative Research. San Francisco, CA: Jossey-Bass.

Collins, C., Landivar, L. C., Ruppanner, L. and Scarborough, W. J. (2021). COVID-19 and the gender gap in work hours. Gender, Work, and Organization, 28(S1), 101-112. DOI: 10.1111/ gwao.12506.

Collings, D. G. and Sheeran, R. (2020). Research insights: Global mobility in a post-covid world. Irish Journal of Management, 39(2): 77-84. DOI: 10.2478/ijm-2020-0002.

Collings, D. G. and Isichei, M. (2018). The shifting boundaries of global staffing: integrating global talent management, alternative forms of international assignments and non-employees into the discussion. The International Journal of Human Resource Management, 29(1): 165-187. DOI: 10.1080/09585192.2017.1380064.

Collings, D. G., Nyberg, A. J., Wright, P. M. and McMackin, J. (2021). Leading through paradox in a COVID-19 world: Human Resources comes of age. 
Human Resource Management Journal, [online first] DOI: 10.1111/1748-8583.12343.

Collings, D. G., Scullion, H. and Dowling, P. J. (2009). Global staffing: a review and thematic research agenda. The International Journal of Human Resource Management, 20(6):1253-1272. DOI: 10.1080/09585190902909806.

Collings, D. G., Scullion, H. and Morley, M. J. (2007). Changing patterns of global staffing in the multinational enterprise: Challenges to the conventional expatriate assignment and emerging alternatives. Journal of World Business, 42(2): 198-213.

Connelly, M. and Clandinin, D. J. (1990). Stories of experience and narrative inquiry. Educational Researcher, 19, 2-14.

Connelly, M. and Clandinin, D. J. (2006). Narrative inquiry. In J. Green, G. Camilli and P. Elmore (Eds.), Handbook of Complementary Methods in Education Research (pp. 477-88). Mahwah, NJ: Lawrence Erlbaum.

Cook, lan (2021). Who is driving the great resignation? Harvard Business Review, [online] https://hbr. org/2021/09/who-is-driving-the-great-resignation (accessed 8 October 2021).

Cooper, C. D. and Kurland, N. B. (2002). Telecommuting, professional isolation and employee development in public and private organizations. Journal of Organizational Behavior, 23, 511-532. DOI: 10.1002/job.145.

Crowley-Henry, M., Benson, E. and Al Ariss, A. (2019). Linking talent management to traditional and boundaryless career orientations: Research propositions and future directions. European Management Review, 16, 5-19. DOI: 10.1111/ emre.12304.

Deloitte Insights (2020). The Fourth Industrial Revolution: At the Intersection of Readiness and Responsibility. UK: Deloitte Touché Tohmatsu Limited. Available at: https://www2.deloitte. com/content/dam/insights/us/articles/us32959industry-4-0/DI_Industry4.0.pdf (accessed 5 July 2020).

Denzin, N. (1997). Interpretive Ethnography: Ethnographic Practices for the 21st Century. Thousand Oaks, CA: Sage.

Eurofound (2018a). Automation, digitalisation and platforms: Implications for work and employment. Publications Office of the European Union, Luxembourg.

Eurofound (2018b). New forms of employment. Update, Publications Office of the European Union, Luxembourg.
Friedman, Z. (2020). How COVID-19 Will Change the Future of Work. Forbes, May 6. [online] Available at: https://www.forbes.com/sites/ zackfriedman/2020/05/06/covid-19-future-of-workcoronavirus/\#5b1320a273b2.

Frone, M. R. (2018). What happened to the employed during the Great Recession? A U.S. population study of net change in employee insecurity, health, and organizational commitment. Journal of Vocational Behavior, 107, 246-260.

Fuller, J. B., Wallenstein, J. K., Raman, M. and de Chalendar, A. (2019). Future Positive: How Companies Can Tap into Employee Optimism to Navigate Tomorrow's Workplace. White Paper (May, 2019). Boston: Harvard Business School. Available at: https://www.hbs.edu/managing-thefuture-of-work/research/Documents/Future $\% 20$ Positive\%20Report.pdf (accessed 7 July 2020).

Giddens, A. (1991). Modernity and Self-Identity. Self and Society in the Late Modern Age. Cambridge: Polity Press.Guan, Y., Deng, $\mathrm{H}$. and Zhou, X. (2020). Understanding the impact of the COVID-19 pandemic on career development: Insights from cultural psychology, Journal of Vocational Behavior, 119, 103438-103438.

Guitton, M. J. (2020). Cyberpsychology research and COVID-19. Computers in Human Behavior, 111, 106357-106357.

Gunasekara, A., Bertone, S., Almeida, S., and CrowleyHenry, M. (2021). Dancing to two tunes: The role of bicultural identity and strong ties in skilled migrants' value-driven protean careers. International Journal of Intercultural Relations, 81, 42-53. DOI: 10.1016/j. ijintrel.2020.12.007.

Gunz, H. and Mayrhofer, W. (2018). Rethinking Career Studies. Facilitating Conversation Across Boundaries with the Social Chronology Framework. Cambridge, England: Cambridge University Press.

Hill, E. J., Miller, B. C., Weiner, S. P. and Colihan, J. (2006). 'Influences of the virtual office on aspects of work and work/life balance'. Personnel Psychology, 51(3), 667-683. DOI: 10.1111/j.17446570.1998.tb00256.x.

Hite, L. M. and McDonald, K. S. (2020). Careers after COVID-19: challenges and changes. Human Resource Development International, 23(4), 427437.

Huws, U. Spencer, N., Coates, M., Sverre Syrdal, D. and Holts K. (2019). The platformisation of work in Europe: Results from research in 13 European countries: UHRA [online] Available at: https://uhra. herts.ac.uk/handle/2299/21600. 
Hyman, J. and Summers, J. (2004). Lacking balance? Work-life employment practices in the modern economy. Personnel Review, 33(: 4), 418-429.

IOM (2020). World Migration Report 2020. Available online: http://www.iom.int/wmr (accessed 20 November 2021).

Kelliher, C. and Anderson, D. (2010). Doing more with less? Flexible working practices and the intensification of work. Human Relations, 63(1), 83-106. DOI: 10.1177/0018726709349199.

Kelliher, C., Richardson, J. and Boiarintseva, G. (2019). All of work? All of life? Reconceptualising work-life balance for the 21st century. Human Resource Management Journal, 29(2), 97-112. DOI: 10.1111/1748-8583.12215.

Kowalski, T. H. P. and Loretto, W. (2017). Well-being and HRM in the changing workplace. The International Journal of Human Resource Management, 28(16), 2229-2255.

Kreiner, G. E. (2006). Consequences of work-home segmentation or integration: a person-environment fit perspective. Journal of Organizational Behavior, 27(4), 485-507.

Mann, S. and Holdsworth, L. (2003). The psychological impact of teleworking: Stress, emotions and health. New Technology Work and Employment, 18, 196211.

Mayrhofer, W., Smale, A., Briscoe, J., Dickmann, M. and Parry, E. (2020). Laying the foundations of international careers research. Human Resource Management Journal, 30: 327-342. DOI: 10.1111/1748-8583.12295.

Mc Kinsey (2017). Digitally-enabled automation and artificial intelligence: Shaping the future of work in Europe's digital front-runners. [online] Available at: https://www.mckinsey.com/featured-insights/ future-of-work (accessed 31 October 2020).

Mills, C. W. (2000 [1959]). The Sociological Imagination. New York: Oxford University Press.

Nohe, C., Meier, L. L., Sonntag, K. and Michel, A. (2015). The chicken or the egg? A meta-analysis of panel studies of the relationship between work-family conflict and strain. Journal of Applied Psychology, 100(2), 522-536.
O'Connor, E. and Crowley-Henry, M. (2020). From home to host: The instrumental kaleidoscopic careers of skilled migrants. Human Relations, 73(2): 262-287.

O'Leary, Z. (2014). The Essential Guide to Doing your Research Project (2nd ed.). Thousand Oaks, CA: SAGE Publications, Inc.

Restubog, S. L. D., Ocampo, A. C. G. and Wang, L. (2020). Taking control amidst the chaos: Emotion regulation during the COVID-19 pandemic. Journal of Vocational Behavior, 119, 103440-103440.

Spurk, D. and Straub, C. (2020). Flexible employment relationships and careers in times of the COVID-19 pandemic. Journal of Vocational Behavior, 119, 103435-103435.

Tharenou, P. (2015). Researching expatriate types: The quest for rigorous methodological approaches. Human Resource Management Journal, 25: 149165.

Tharenou, P. and Kulik, C.T. (2020). Skilled migrants employed in developed, mature economies: From newcomers to organisational insiders. Journal of Management, 46(6), 1156-1181.

Toniolo-Barrios, M. and Pitt, L. (2021). Mindfulness and the challenges of working from home in times of crisis. Business Horizons, 64(2), 189-197.

Webb, E. J., Campbell, D. T., Schwartz, R. D. and Sechrest, L. (2000). Unobtrusive Measures. Thousand Oaks, CA.; London: Sage.

Weick, K. E. (1995). Sensemaking in Organizations. Thousand Oaks, Ca.; London: Sage.

WHO (2020). World Health Organisation Timeline of WHO's Response to COVID-19 [online] 29 June 2020. Available at: https://www.who.int/newsroom/detail/29-06-2020-COVIDtimeline (accessed 18 July 2020).

Wilkinson, D. and Thelwall, M. (2011). Researching personal information on the public web: Methods and ethics. Social Science Computer Review, 29(4), 387-401.

World Bank (2019). World Development Report 2019: The Changing Nature of Work. Washington, DC: World Bank. DOI:10.1596/978-1-4648-1328-3.

Yildirim, T. M. and Eslen-Ziya, H. (2021). The differential impact of COVID-19 on the work conditions of women and men academics during the lockdown. Gender, Work, and Organization, 28(S1), 243-249. 